\title{
Measuring Socio-economic Profile of Farmers to Climate Change in Uttarakhand, India
}

\author{
Rupan Raghuvanshi*, M.A. Ansari and Amita Yadav
}

Department of Agricultural Communication, College of Agriculture G.B. Pant University of Agriculture and Technology, Pantnagar, Uttarakhand (263145), India

*Corresponding author

\section{A B S T R A C T}

\section{Keywords}

Climate change,

Socio-economic profile, Farmers

Article Info

Accepted:

28 June 2018

Available Online:

10 July 2018
Climate change is important emerging issue in the field of agriculture. So it is important to study the socio-economic characteristics of farmers before designing any adaptation and mitigation programmes for the farmers. Hence a study was conducted in the Garhwal and Kumaon region of Uttarakhand to investigate the socio-economic profile of farmers. Primary data was collected through semi structured interview schedule using a sample of 200 farmers selected from four districts. Data was analysed through frequency, range and percentage. It was found that majority of farmers were middle aged, posses small landholding, educated up to high school and had income between 5001-9999. It was also found that maximum no. of farmers had Individual drinking water facility along with pakka drainage and Individual sanitary toilet with water facility. It was also found that more than half of the respondents do not have any official position in the society.

\section{Introduction}

Climate change is a global phenomenon which impacted all the sectors in different ways. Agriculture sector is highly dependent on climate variables, hence more affected by the climate change. Developing countries are more vulnerable to climate change as compare to developed countries. India is more vulnerable to climate change as one third of its population depends on agriculture for survival. Climate change projections for India for the 2050s suggest an increase in temperature of 2 $4^{\circ} \mathrm{C}$ for the country's south and of more than $4^{\circ} \mathrm{C}$ for its northern region (Kumar, 2018).
Scientists also predict an increase in the intensity and frequency of extreme events such as droughts, floods and cyclones. There is a shift in the pattern of mansoons, rainfall becomes erratic and irregular and fluctuation in temperatures. These local climatic fluctuations have direct impact in agriculture; reduces the crop production and productivity both in terms of quality and quantity. To cope up with climate change, farmers adopt some adaptation measures like shift in crop rotation according to climate, growing of less water intensive crops, growing of high yielding varieties etc. (Rupan and Ansari, 2016). 
The mountainous state such as Uttarakhand, is more sensitive and most vulnerable to climate mediated risks. Climate and weather determine food security of the hill communities, who depends on agriculture and animal husbandry for their subsistence needs. Most of the farmers had small and scattered land holding. Temperature, precipitation and their associated seasonal patterns are critical components of agricultural production. When the agricultural sector is vulnerable to climate mediated riskes, agriculture also varies in several economic factors, such as total production quantity, profit margin of crops, profit margin of final goods, farm and offfarm wage rate etc. As a consequence of this the socioeconomic profiles farmers are changing with the changing climate. The climatic factors affect, directly or indirectly, the social and economical status of the farmers. Climate changes cause crop damages, low productivity and high production cost that lead to losses of farmers' income, poverty level increases, and seasonal unemployment rates increase (Siwar, et.al, 2009). According to Rupan et.al (2018) farming community for adopting adaptation practices therefore requires sustained agriculture extension strategies and relevant policy measures for mitigating adverse impact of climate change

To study the farmers profile before planning any adaptation and mitigation stratigies for farmers at local level is important. So an attempt was made to study the socioeconomic profile of the hilly farmers under current climatic change scenario in the Himalayan range of Uttarakhnd.

\section{Materials and Methods}

Total four districts Tehri and Uttarkashi from Garhwal region and Nainital and Bageshwar from Kumaon region were selected on the basis of purposive sampling technique. Two villages from each district, hence total 8 villages were selected through proportional sampling technique. A sample of 200 hundred farmers was used. Primary data was collected through interview-schedule, observation and focused group discussion methods. Data was collected personally by the researches in the farmers field and home. The collected data was analysed through appropriate statistical tools; average, range, frequency and percentage.

\section{Results and Discussion}

The socio-economic profile of the farmers includes; age, gender, income, education, occupation, social participation, information seeking behaviour and mass media exposure.

\section{Age}

Majority of the respondent $(54.5 \%)$ belonged to middle age(46 to 67 years) group followed by 31 percent of those who belonged to young age( less than 46 year) category. Only 14.5 percent were from old age category (more than 67 year).

\section{Agricultural Land Holding}

The data reveals that most of the respondents were small farmers (96\%) having land less than 34 naali followed by medium farmers (3\%) who had 34 to 66 naali. Only one percent of respondents were large farmers who had more than 66 naali landholding.

\section{Education}

It is revealed from the table that maximum number of the respondents (31.5\%) were educated up to high school followed by 22.5 percent of respondents who were educated up to Intermediate level and 16.5 percent respondents were educated up to primary education level. It was also found that 8.5 percent of respondents were graduated, 8 percent were illiterate and 4.4 percent of 
respondents were functionally literate and same as were having the post graduate degree. Only 4 percent was done technical diploma.

\section{Occupation}

It was found that majority $(25.5 \%)$ of the respondents; the head of households were engaged in agriculture followed by 21 percent of respondents who were skilled workers and 14 percent who were semi skilled worker. Unskilled workers were 9 percent followed by 8 percent who were shop owner. Professionals were 6.5 percent same as semi professionals. Only 2 percent of respondents were unemployed.

\section{Income}

Data reveals that of most of the respondents (29.5\%) had monthly family income from Rs.5000 to 9999 followed by 22 percent of respondents who had monthly family income from Rs. 15000 to19999. Monthly family income of 17.5.percent respondents was from Rs. 10000 to 14999 , 10.5 percent respondents were from Rs.20000 to 24999 and 11 percent respondents was up to 5000. It was also seen that 10.5 percent of respondents and 7.5 percent of respondents had Rs. 20000 to 24999 Rs. 25000-29999 monthly family income respectively. Only 2 percent of respondents had monthly family income more than 30000 .

Table.1 Distribution of respondents on the bases of socio-economic status $(n=200)$

\begin{tabular}{|c|c|c|c|}
\hline $\begin{array}{c}\text { S. } \\
\text { No. }\end{array}$ & Category & Frequency & Percentage \\
\hline 1 & $\begin{array}{l}\text { Age } \\
\text { Young ( Less than 46) } \\
\text { Middle aged (46 to 67) } \\
\text { Old( More than 67) }\end{array}$ & $\begin{array}{c}62 \\
109 \\
29\end{array}$ & $\begin{array}{c}31 \\
54.5 \\
14.5\end{array}$ \\
\hline 2 & $\begin{array}{l}\text { Landholding } \\
\text { Small farmer (Less than } 34 \text { naali) } \\
\text { Medium farmer ( } 34 \text { to } 66 \text { naali) } \\
\text { Large farmer ( More than } 66 \text { naali) }\end{array}$ & $\begin{array}{c}192 \\
6 \\
2\end{array}$ & $\begin{array}{c}96 \\
3 \\
1\end{array}$ \\
\hline 3 & $\begin{array}{l}\text { Education } \\
\text { Illiterate } \\
\text { Functionally literate } \\
\text { Primary education } \\
\text { High school } \\
\text { Intermediate } \\
\text { Graduate } \\
\text { Technical diploma } \\
\text { Post graduate }\end{array}$ & $\begin{array}{c}16 \\
9 \\
33 \\
63 \\
45 \\
17 \\
8 \\
9\end{array}$ & $\begin{array}{c}8 \\
4.5 \\
16.5 \\
31.5 \\
22.5 \\
8.5 \\
4 \\
4.5\end{array}$ \\
\hline
\end{tabular}




\begin{tabular}{|c|c|c|c|}
\hline 4 & $\begin{array}{l}\text { Occupation } \\
\text { Unemployed }\end{array}$ & 4 & 2 \\
\hline & Unskilled workers & 18 & 9 \\
\hline & Semi-skilled workers & 28 & 14 \\
\hline & Skilled workers & 42 & 21 \\
\hline & Clerical & 15 & 7.5 \\
\hline & Shop owner & 16 & 8 \\
\hline & Farming & 51 & 25.5 \\
\hline & Semi-professionals & 13 & 6.5 \\
\hline & Professionals & 13 & 6.5 \\
\hline \multirow[t]{7}{*}{5} & $\begin{array}{l}\text { Income } \\
\text { Up to } 5000\end{array}$ & 22 & 11 \\
\hline & $5001-9999$ & 59 & 29.5 \\
\hline & 10000-14999 & 35 & 17.5 \\
\hline & $15000-19999$ & 44 & 22 \\
\hline & $20000-24999$ & 21 & 10.5 \\
\hline & $25000-29999$ & 15 & 7.5 \\
\hline & 30000 and more & 4 & 2 \\
\hline \multirow[t]{4}{*}{6.} & $\begin{array}{l}\text { Water facilities } \\
\text { Drinking water available with } \\
\text { community source with drainage }\end{array}$ & 47 & 23.5 \\
\hline & $\begin{array}{l}\text { Drinking water available for 2-3 house } \\
\text { or share the same source with kaccha } \\
\text { drainage }\end{array}$ & 30 & 15 \\
\hline & $\begin{array}{l}\text { Individual drinking water facility } \\
\text { along with kaccha drainage }\end{array}$ & 37 & 18.5 \\
\hline & $\begin{array}{l}\text { Individual drinking water facility } \\
\text { along with pakka drainage }\end{array}$ & 86 & 43 \\
\hline
\end{tabular}




\begin{tabular}{|c|l|c|c|}
\hline 7. & $\begin{array}{l}\text { Sanitation } \\
\text { No availability of toilet }\end{array}$ & 49 & 24.5 \\
\hline & Individual pit toilet & 10 & 20 \\
\hline & $\begin{array}{l}\text { Individual sanitary toilet without } \\
\text { water facility }\end{array}$ & 40 & 50.5 \\
\hline & $\begin{array}{l}\text { Individual sanitary toilet with water } \\
\text { facility }\end{array}$ & 101 & 51.5 \\
\hline $\mathbf{8 .}$ & $\begin{array}{l}\text { Social participation } \\
\text { Without any official position }\end{array}$ & 103 & 39 \\
\hline & $\begin{array}{l}\text { Without any official position but } \\
\text { active participation in villages }\end{array}$ & 78 & 2 \\
\hline $\begin{array}{l}\text { Official position in more than one } \\
\text { villages }\end{array}$ & $\begin{array}{l}\text { Financial contribution or raising } \\
\text { fund for common work }\end{array}$ & 7.5 \\
\hline
\end{tabular}

\section{Drinking water facilities}

Most of the respondents (43\%) had individual drinking water facility along with pakka drainage followed by 23.5 percent of respondents who had drinking water available with community source with drainage. It was also found that 18.5 percent of respondents were having individual drinking water facility along with kaccha drainage. Further 15 percent of respondents were had drinking water available for 2-3 house or share the same source with kaccha drainage.

\section{Sanitation facility}

It was found that half of the respondents $(50.5 \%)$ were had individual sanitary toilet with water facility followed by 24.5 percent of respondents who had no toilet availability. It was also found that 20 percent of respondents had Individual sanitary toilet without water facility and only 5 percent of respondents have individual pit toilet.

\section{Social participation}

It is evident from the data that around half of respondents $(51.5 \%)$ do not have any official position and 39 percent of respondents were actively involved in village activities without any official position. It was also depicted that only 7.5 percent of respondents involved in financial contribution or raising fund for common work and only 2 percent had official position in more than one village.

In conclusion, socio-economic profile of farmers becomes important in designing and development of various mitigation and adaptation techniques for farmers at grass root level. From the fact and findings it can be concluded that majority of farmers were middle aged, posses small landholding, educated up to high school, farming is the main occupation of respondents in the study area. Majority of them had income between 5001- 9999. Maximum no. of farmers had Individual drinking water facility along with pakka drainage and Individual sanitary toilet with water facility. It was also found that more than half of the respondents do not have any official position in the society. Therefore it becomes important to the policy makers to study the socio-economic profile of the farmers before designing any adaptation and mitigation strategies to deal with the changing climatic conditions. 


\section{References}

Kumar, R., 2018. Impact of climate change on Indian agriculture. Available from: https://www.researchgate.net/publicati on/277147408_Impact_of_climate_ch ange_on_Indian_agriculture accessed on Jun 192018.

Raghuvanshi R. and Ansari, M. A.2016. Farmer's Awareness about Climate Change and Adaptation Practices: A Review. Research \& Reviews: Journal of Agricultural Science and Technology. 5(3).pp-41-51.
Raghuvanshi, R., Ansari M.A.,Amardeep and Verma, A.P., 2018. Adaptation to climate change by farmers in Himalayan Region of Uttarakhnd. Research Journal of Agriculture Sciences. 9(2): 399-403.

Siwar, C., Alam, M.M., Murad, M.W. and Alamin, A.Q., 2009. A review of the linkages between climate change, agricultural sustainability and poverty in Malaysia. International Review of Business Research Papers, 5, 309321.

\section{How to cite this article:}

Rupan Raghuvanshi, M.A. Ansari and Amita Yadav. 2018. Measuring Socio-economic Profile of Farmers to Climate Change in Uttarakhand, India. Int.J.Curr.Microbiol.App.Sci. 7(07): 4035-4040. doi: https://doi.org/10.20546/ijcmas.2018.707.469 